\title{
Effects of grass-red clover silage digestibility and concentrate protein concentration on performance, carcass value, eating quality and economy of finishing Hereford bulls reared in cold conditions
}

Merja Manninen $^{1 *}$, Markku Honkavaara ${ }^{2}$, Lauri Jauhiainen ${ }^{3}$, Arja Nykänen ${ }^{4}$ and Anna-Maija Heikkilä ${ }^{1}$

\author{
${ }^{I}$ MTT Agrifood Research Finland, Economic Research, FI-00410 Helsinki, Finland \\ ${ }^{2}$ Finnish Meat Research Institute, FI-13110 Hämeenlinna, Finland \\ ${ }^{3}$ MTT Agrifood Research Finland, Services Unit, FI-31600 Jokioinen, Finland \\ ${ }^{4}$ MTT Agrifood Research Finland, Plant Production Research, FI-50100 Mikkeli, Finland \\ *Present address: Evira, Finnish Food Safety Authority, Control department, FI-32200 Loimaa, Finland, \\ email:merja.manninen@evira.fi
}

\begin{abstract}
The aim of the present experiment was to study the effects of (1) digestibility of grass-red clover silage (GCS) and (2) concentrate protein concentration on the performance, eating quality and economy of Hereford bulls during a six months pre-slaughter period, and reared in cold indoor facilities. Thirty-one bulls with an initial live weight (LW) of $289 \mathrm{~kg}$ were selected for a $2 \times 2$ factorial design experiment consisting of two primary growth GCSs harvested at different maturities (in vitro digestible organic matter (OM) in dry matter (DM), D value: Early-cut, E, $750 \mathrm{~g} \mathrm{~kg}^{-1} \mathrm{DM}$; Late-cut, L, $699 \mathrm{~g} \mathrm{~kg}^{-1} \mathrm{DM}$ ) and two concentrate crude protein concentrations (Medium, M, $170 \mathrm{~g} \mathrm{~kg}^{-1} \mathrm{DM}$; High, H, $210 \mathrm{~g} \mathrm{~kg}^{-1} \mathrm{DM}$ ). The concentrate comprised milled barley and pelleted commercial protein compound and was offered daily on average $3.2 \mathrm{~kg} \mathrm{DM}$, including 0.45 and $1.13 \mathrm{~kg}$ of rapeseed cake in $\mathrm{M}$ and $\mathrm{H}$, respectively. Grass-red clover silage was offered ad libitum. The target cold carcass weight was $330 \mathrm{~kg}$. The proportion of concentrate of the total daily DM intake averaged 0.337 during the entire experiment. Treatments had no effect on the daily intake of GCS, total intake of DM, DM intake $\mathrm{kg}^{-1} \mathrm{LW}^{0.75}$ and metabolizable energy averaging 6.0 and 9.4 kg DM, 97.4 $\mathrm{g}$ and 109.4 MJ, respectively. The digestibility of dietary OM and neutral detergent fibre was lower $(p<0.05,0.733$ vs. 0.769 and 0.625 vs. 0.665$)$ on $\operatorname{diet} \mathrm{L}$ than on $\operatorname{diet} \mathrm{E}$. The animals on $\operatorname{diet} \mathrm{E}$ tended to consume daily on average $1.29 \mathrm{~kg}$ less $(p<0.10) \mathrm{DM} \mathrm{kg}^{-1}$ net weight gain than those on diet $\mathrm{L}$. The time to achieve the target carcass weight was on average 18 days longer $(p<0.01)$ on diet $\mathrm{L}$ than on diet E. During the entire experiment the LW gain averaged 1795 and $1609 \mathrm{~g} \mathrm{~d}^{-1}(p<0.01)$ on diets E and $\mathrm{L}$, respectively. The concentrate protein concentration did not affect animal performance. Treatments had no significant effect on the kill-out proportion, EUROP carcass conformation and carcass fat classification which averaged $537 \mathrm{~g} \mathrm{~kg}^{-1}, 6.5$ and 3.6, respectively. The eating quality of the tested loins was good. Treatments had only a minor effect on the yield of valuable cuts. It is concluded that the digestibility of silage is important since the early-cut silage improved the growth rate and shortened the finishing period of bulls significantly compared with those fed late-cut silage. The lower yield and, thus, higher unit cost of early-cut silage may, however, invalidate its superiority compared with the late-cut silage. There was no benefit from using concentrate of high protein concentration.
\end{abstract}

Key-words: Beef production, concentrate protein concentration, economy, eating quality, silage digestibility 
Manninen, M. et al. Silage digestibility and concentrate protein in feeding of bulls

\section{Introduction}

Beef production from suckled beef-breed calves is increasing in Finland. The feeding of finishing cattle is largely based on grass silage. The nutritive value of this depends on the stage of growth at harvesting and the changes in the chemical composition during ensiling (e.g. Beever et al. 2000, Huhtanen et al. 2007). During the primary growth of grass, the daily decline in $\mathrm{D}$ value (digestible organic matter $(\mathrm{OM})$ in dry matter (DM), $\left.\mathrm{g} \mathrm{kg}^{-1} \mathrm{DM}\right)$ in Finnish conditions with timothy-meadow fescue grasses has typically been $5 \mathrm{~g} \mathrm{~kg}^{-1} \mathrm{DM}$ (Rinne et al. 1999, Rinne et al. 2002) but lower values have been reported for the harvest of primary growth perennial ryegrass herbage (Keady et al. 2000). If the silage contains red clover, the decline is slower (Rinne and Nykänen 2000). According to Kuoppala et al. (2008), postponing the harvest of primary growth grass decreased silage DM intake (DMI) of dairy cows by $0.48 \mathrm{~kg}$ and the energy-corrected milk yield by $0.61 \mathrm{~kg} 10$ $\mathrm{g}^{-1}$ decrease in silage D value. On the other hand, postponing the silage harvest increases the DM yield $\mathrm{ha}^{-1}$ and thus decreases the unit cost of silage DM. With growing cattle, several studies have confirmed that harvesting primary growth grass at an earlier stage of maturity improved the animal growth rate (e.g. Scollan et al. 2001, Nadeau et al. 2002, Steen et al. 2002, Keady et al. 2008). According to Steen (1988a), increasing the digestibility of grass silage by harvesting the grass at an earlier stage of growth may be the most effective method of increasing animal performance from silage.

In Finland, most producers use varying amounts of protein supplements with grain on grass silagebased diets. Protein supplementation for finishing cattle has been studied extensively, but the responses to supplementation have been inconsistent. The discrepancies may be due to the differences in animal live weight (LW) and the nutritive value of roughage as well as the amount and type of supplement offered. Additionally, the response to protein supplementation may depend on total diet crude protein concentration, stage of maturity of the beef animal and gender. At present, rapeseed is the most important protein supplement used for cattle in Finland and most of the commercial protein compounds available are based on rapeseed meal or rapeseed cake. In earlier studies with light (final LW between approximately 390 and $510 \mathrm{~kg}$ ) dairybreed bulls (Aronen 1990, Aronen et al. 1992), rapeseed meal supplementation increased the animal growth rate, particularly at the beginning of the finishing period, partly due to an increased silage and energy intake. In several studies, protein supplementation has not increased the growth rate (e.g. Steen 1996a, Huuskonen et al. 2008, Huuskonen 2009a), but there is evidence that finishing cattle may respond to supplementary protein in barleybased concentrates when the grass silage digestibility is moderate or low (Waterhouse et al. 1985) and in situations where the animals have very high growth potential (Steen 1996b). In some studies, excess protein supplementation has increased carcass fat classification (Steen and Moore 1988, 1989, Steen 1996a) but Berge et al. (1993) reported that steers which were given protein supplementation had leaner carcasses than steers not given protein supplementation. Meat tenderness is the most important property of beef meat for consumers and it has been studied widely (e.g. Berge et al. 1993, Manninen et al. 2010) but the effects of protein supplementation on high digestible grass silage-based diet on eating quality are scarce. Furthermore, overfeeding of protein may cause extra costs to beef producers and load to the animals' metabolism and environment.

No studies, made in Nordic conditions having timothy-meadow fescue grasses, are available on the effects of silage digestibility and protein supplementation with a low amount of concentrate on the performance of animals having a high growth potential. Therefore, the aim of the present experiment was to study the effects of grass-red clover silage (GCS) digestibility and concentrate protein concentration during a six months pre-slaughter period with Hereford (Hf) bulls, and reared in cold indoor facilities. However, the best economic performance is not necessarily reached with the feeding strategy that gives the best biological results. The effects of treatments on feed intake, diet digestibility, animal growth rate, feed conversion, carcass and eating quality, yield of valuable cuts and, finally, on the economy are discussed in this paper. 
Vol. 20(2011): 151-168.

\section{Material and methods}

\section{Animals, experimental design and housing facilities}

The experiment was carried out at Tohmajärvi Research Station, MTT Agrifood Research Finland, located in eastern Finland $\left(62^{\circ} 20^{\prime} \mathrm{N}, 30^{\circ} 13^{\prime} \mathrm{E}\right)$ where the average vegetation growth period is 155 days. Thirty-two Hf bulls were taken for the experiment but one animal was removed from the experiment on 26 January due to acute lameness, possibly due to muscle injury. All data for this animal is deleted. Therefore, thirty-one Hf bulls (the dams were Hf cows) with an initial LW of $289 \mathrm{~kg}$ (standard deviation (SD) $37.7 \mathrm{~kg}$ ) and age of $225 \mathrm{~d}$ (SD $22.6 \mathrm{~d}$ ) on 18 November were selected for the experiment. The bulls were born at the Research Station between 13 March and 10 June (17 in March, nine in April, three in May and two in June). The birth weight averaged $42.0 \mathrm{~kg}$ (SD $4.81 \mathrm{~kg}$ ). At pasture, dam milk and grass were the sole feeds for the bulls. From weaning on 17 September to the onset of the experiment on 19 November, the bulls were kept in an uninsulated barn and had free access to grass silage. During the last two weeks pre-experiment, milled barley, at most $2.0 \mathrm{~kg} \mathrm{DM} \mathrm{d}^{-1}$, was given to facilitate adaptation to the experimental diet. The daily live weight gain (LWG) from birth to the onset of the experiment averaged $1097 \mathrm{~g}$ (SD $128.7 \mathrm{~g}$ ).

In the present experiment, four treatments in a $2 \times 2$ factorially arranged design consisted of two primary growth digestibilities, GCSs (Early-cut, E; Late-cut, L) and two concentrate crude protein (CP) concentrations (Medium, M; High, H). Initial LW, age and sire were used to allocate the animals to four groups. Thereafter, the treatments were randomly assigned to groups. The animals were group-fed, four animals per pen and two pens per treatment. The two pens for each treatment were allotted in the barn so that pens having same treatment were not alongside.

During the experiment the animals were kept in an uninsulated barn in eight pens. Each pen was $37 \mathrm{~m}^{2}$, including $26.5 \mathrm{~m}^{2}$ of bedding area and 10.5 $\mathrm{m}^{2}$ of passage. Straw and peat were used as bed- ding materials. The bulls had access to an asphalted outdoor exercise area of $53 \mathrm{~m}^{2}$ for one to two hours two to three times weekly while bedding material was added. During the experiment the temperature in the barn was measured daily at 8:00 and 14:00 hours. The coldest temperature $\left(-20.7^{\circ} \mathrm{C}\right)$ was measured on 12 February at 8:00 hours and the highest temperature $\left(+23.3^{\circ} \mathrm{C}\right)$ on 7 May at $14: 00$ hours. The mean temperature during the experimental months was $+2.0^{\circ} \mathrm{C}$.

\section{Feeds and feeding}

The aim was to have silages with $\mathrm{D}$ values of 700 and $650 \mathrm{~g} \mathrm{~kg}^{-1} \mathrm{DM}$, but the target was not met due to weather conditions. Wilted silages were harvested from two fields at the Research Station, 17-18 June (E) and 31 June-1 July (L), with a mower conditioner and a precision chopper. The herbage was ensiled in bunker silos using a formic acid-based additive (AIV 2 Plus: formic acid $760 \mathrm{~g} \mathrm{~kg}^{-1}$, ammonium formate $55 \mathrm{~g} \mathrm{~kg}^{-1}$, Kemira Oyj, Oulu, Finland) applied at 51 $\mathrm{t}^{-1}$ fresh weight. The sward for silage was a secondyear timothy (Phleum pratense L.), meadow fescue (Festuca pratensis Huds.), red clover (Trifolium pratense L.) mixture sown in the proportions 650 , 300 and 50 seeds $\mathrm{m}^{-2}$, respectively. The sward was fertilized in spring using nitrogen (N) $33.5 \mathrm{~kg} \mathrm{ha}^{-1}$. The energy value of the GCS was evaluated prior to the experiment using in vitro $\mathrm{OM}$ digestibility (OMD, Friedel 1990).

The concentrate comprised milled barley and pelleted commercial protein compound (CPC), having a $\mathrm{CP}$ concentration of either $170(\mathrm{M})$ or $210(\mathrm{H}) \mathrm{g} \mathrm{kg}^{-1} \mathrm{DM}$. The energy content in $\mathrm{M}$ and $\mathrm{H}$ was 12.88 and $12.55 \mathrm{MJ}$ metabolizable energy (ME) $\mathrm{kg}^{-1} \mathrm{DM}$, respectively. Thus, the difference between $\mathrm{M}$ and $\mathrm{H}$ was $0.33 \mathrm{MJ} \mathrm{ME} \mathrm{kg}^{-1} \mathrm{DM}$. Barley was milled using a $7 \mathrm{~mm}$ riddle. The CPC (the diameter of pills was $5 \mathrm{~mm}$, Futura-Maituri $140 \mathrm{~L}$, Raisio Feed Ltd, Raisio, Finland) included rapeseed cake $\left(680 \mathrm{~g} \mathrm{~kg}^{-1}\right)$, wheat bran $\left(105 \mathrm{~g} \mathrm{~kg}^{-1}\right)$, molassed sugarbeet pulp (70 $\left.\mathrm{g} \mathrm{kg}^{-1}\right)$, mixed molasses $\left(50 \mathrm{~g} \mathrm{~kg}^{-1}\right)$, wheat middlings $\left(42 \mathrm{~g} \mathrm{~kg}^{-1}\right)$, oat bran $\left(30 \mathrm{~g} \mathrm{~kg}^{-1}\right)$, calcium carbonate $\left(11 \mathrm{~g} \mathrm{~kg}^{-1}\right)$, 
Manninen, M. et al. Silage digestibility and concentrate protein in feeding of bulls

sodium chloride $\left(6 \mathrm{~g} \mathrm{~kg}^{-1}\right)$ and premix $\left(6 \mathrm{~g} \mathrm{~kg}^{-1}\right)$. The amount of barley and CPC given was calculated on the basis of the pre-evaluated feed analysis of both feeds. The proportion of CPC in the concentrate was either 0.185 or 0.459 on an air-dry basis in diets $M$ and $H$, respectively. During the experiment the animals received $280 \mathrm{~g} \mathrm{DM} \mathrm{d}^{-1}$ of mineral mixture (Luonnon Viher-Minera: Ca 84, P 34, Na 60 and $\mathrm{Mg} 70 \mathrm{~g} \mathrm{~kg}^{-1}$, Suomen Rehu Oy, Vaasa, Finland). No vitamin mixture was given to the animals.

The concentrate was offered at 2.0, 3.0 and 4.0 $\mathrm{kg} \mathrm{DM} \mathrm{d}{ }^{-1}$ during the periods P1 (56 d), P2 (57 d) and P3 (min $27 \mathrm{~d}$, max $104 \mathrm{~d}$, mean $74 \mathrm{~d}$, SD 22.2 $\mathrm{d}$, until slaughter), respectively. The animals were fed at 7:30 hours. Barley and CPC were spread on the feeding table evenly and, thereafter, the animals were tied up for maximum $2 \mathrm{~h}$ so that each animal could eat its own portion. Silage was offered ad libitum (at least 22 hours per day) during the entire experiment at an excess level of 1.05 of the daily intake. The amount of feeds offered and refused was recorded daily. Water was offered ad libitum via heated water-pipes and -cups.

\section{Feed and faecal sampling and analysis}

The swards were pre-sampled on 11, 18 and 23 June, i.e. once before the harvest of $\mathrm{E}$ and three times before the harvest of $\mathrm{L}$. The $\mathrm{D}$ value and $\mathrm{CP}$ concentration of the sward were determined in order to monitor the change in sward digestibility. The pre-samples were cut by scissors from the swards from four $0.25 \mathrm{~m}^{2}$ areas of the two fields, weighed, dried and analysed for DM content, as well as for D value and CP concentration by FOSS NIR Systems 5000 (Near Infra-Red Spectroscopy, FOSS, Eden Prairie, MN 55344, USA). At the time of harvest, similar samples were taken for botanical analyses to determine the red clover content of the swards. During the experiment, samples of GCS were taken for P1 and P2 and two samples for P3. One representative feed sample, pooled over twelve sub-samples, of barley, CPC and mineral mixture was taken at the onset of the experiment. The CPC and mineral mixture originated from one production batch and the barley from one harvest.

The total-tract apparent $\mathrm{OM}$ and protein as well as neutral detergent fibre (NDF) dietary digestibility were estimated using acid insoluble ash as an internal marker (European Commission 1971). Spot faecal samples were collected from each bull on two occasions, and on each occasion they were taken once daily for three consecutive days. Samples were taken on 3-5 February during P2 and 29 -31 March during P3. The samples were pooled on a pen basis (on a wet basis, equal amount per animal), thoroughly mixed, sub-sampled and stored at $-20^{\circ} \mathrm{C}$. Totally 16 faecal samples were collected and analysed, i.e. one sample per pen per sampling period. Extra feed samples (four GCS samples, two barley samples and two CPC samples) were collected on the faecal collection days.

The GCS, barley, CPC and mineral mixture DM contents were determined by oven drying at $105^{\circ} \mathrm{C}$ for 16 hours and GCS corrected for volatile losses according to Huida et al. (1986). Feed and faecal samples were analysed for ash (AOAC 1990, method No. 942.05), ether extract (AOAC 1990, method No. 920.39A) and crude fibre according to the EEC standard (92/89, ASN 3802) using the FiberCap 2021/2023 system (Foss Tecator AB, Höganäs, Sweden), total $\mathrm{N}$ of mineral mixture by the Dumas method using a Leco FP 428 nitrogen analyser (AOAC 1990, method No. 968.06, Leco Corp., St Joseph, MI 49085, USA) and total N of GCS, barley and CPC using a Foss Kjeltec 2300 Analyzer Unit (Foss Tecator AB, Höganäs, Sweden) and for NDF according to Van Soest et al. (1991). In vitro OMD was measured using a cellulase enzyme complex according to Friedel (1990). Fresh GCS samples were analysed for $\mathrm{pH}$ and water-soluble carbohydrates (WSC) by the method of Somogyi (1945), lactic acid (Haacker et al. 1983), volatile fatty acids (Huhtanen et al. 1998), ammonia N (McCullough 1967) and ethanol with an enzymatic kit (Cat No. 981680, KONE Instruments Corporation, Espoo, Finland) and soluble $\mathrm{N}$ by the Kjeldahl method using $\mathrm{Cu}$ as a digestion catalyst (AOAC 1990, method No. 984.13).

The ME value for GCS was calculated assuming a ME content of $16 \mathrm{MJ} \mathrm{kg}^{-1}$ digestible OM 
Vol. 20(2011): 151-168.

(DOM, MTT 2006). The D value was based on in vitro measurement. The AAT values were calculated using the measured $\mathrm{D}$ value and the $\mathrm{CP}$ concentration (MTT 2006). The intake index (IN) for GCS was calculated according to Huhtanen et al. (2002).

The energy value for barley was calculated using the determined chemical composition and average digestibility coefficients reported by MTT (2006). The energy value for CPC was calculated using the average chemical composition and average digestibility coefficients of each component (MTT 2006).

\section{Live weight, slaughter procedures and eating quality}

The animals were weighed on two consecutive days at the onset of the experiment and at the end of P1, P2 and P3 before feeding. Additionally, the animals were weighed once every 28 days.

The target cold carcass weight was $330 \mathrm{~kg}$. The animals were selected for slaughter based on LW, LWG pre-slaughter and an assumed dressing proportion $(0.550)$ which was assessed based on earlier studies (unpublished data) in Finland with Hf bulls. The animals were slaughtered in 11 slaughter batches, i.e. three batches in April (seven animals in all), four batches in May (ten animals in all) and four batches in June (14 animals in all). Feed was not offered on the morning of slaughter, but there was still silage available for all animals. The animals were slaughtered in the Atria Oyj slaughterhouse in Kuopio, $190 \mathrm{~km}$ away from the Research Station. The time interval from the departure to the slaughter was approximately six hours.

The carcasses were classified for conformation (12 classes: $\mathrm{S}, \mathrm{E}, \mathrm{U}, \mathrm{R}+, \mathrm{R}, \mathrm{R}-, \mathrm{O}+, \mathrm{O}, \mathrm{O}-$ and $\mathrm{P}+$, P, P-) and fat cover (5 classes: 1, 2, 3, 4 and 5) using the EUROP quality classification scale (Commission of the European Communities 1991). The kill-out proportion was calculated as the proportion of cold carcass weight (hot carcass weight $\times$ 0.98; Ministry of Agriculture and Forestry 1995) to final LW and expressed as the proportion of $\mathrm{kg}$ cold carcass weight to $\mathrm{kg}$ final LW. The carcass temperature was chilled below $7{ }^{\circ} \mathrm{C}$ for 24 hours, after which the $\mathrm{pH}$ value of the loin was measured on the $11^{\text {th }}$ rib of a half carcass. The right side of each carcass was then quartered at the $5^{\text {th }}$ rib into a pistola hind quarter without the flank (Swatland 2000). The pistola was cut into valuable cuttings and tallow (subcutaneous fat). It is well known that the most valuable cuts come from the back and whole round of a half carcass. Thus, loin and tenderloin were cut from the back, whereas the whole round cuttings were outside round, inside round, corner round and roast beef. All cuttings and the tallow were weighed and their yields were expressed as percentages of the carcass cold weight $(0.98 \times$ carcass hot weight 50 min post mortem $)$.

During cutting, a loin sample of $2 \mathrm{~kg}$ was taken from between the $5^{\text {th }}$ and $8^{\text {th }}$ ribs and vacuum packaged. After that, samples were sent to the Finnish Meat Research Institute (LTK) for further analyses. At LTK, the loin samples were aged for 17 days at $4{ }^{\circ} \mathrm{C}$, making a total ageing time of 19 days, and thereafter frozen $\left(-20{ }^{\circ} \mathrm{C}\right)$ for four months before sensory evaluation and shear force value measurement. After thawing, the organoleptic quality and shear force value of the loins were analysed. For the organoleptic evaluation, four $1.5 \mathrm{~cm}$ slices from each loin were heated to $68{ }^{\circ} \mathrm{C}$ in a rolling grill (Palux Rotimat, Germany) and evaluated by six trained sensory panellists for tenderness, juiciness and taste. These traits were scored on a 7-point scale ( $4=$ satisfactory, $5=$ good, $6=$ desirable and $7=$ most desirable). In addition, the panellists recorded off-flavours, if any, during the organoleptic evaluation.

For shear force value measurements loin samples were heated in a water bath of $85^{\circ} \mathrm{C}$ until the core temperature of meat was $70^{\circ} \mathrm{C}$. After chilling for 24 hours $\left(4{ }^{\circ} \mathrm{C}\right)$, loin samples of about $6 \mathrm{~cm}$ long (parallel to the myofibres), $1 \mathrm{~cm}$ high and 1 $\mathrm{cm}$ wide (square probe of $1 \mathrm{~cm} \times 1 \mathrm{~cm}$ surface area) were placed in a Warner-Bratzler shear blade to be sheared perpendicularly to the muscle fibre longitudinal axis in Instron testing machine. Maximum force was recorded and results were expressed as $\mathrm{kg} \mathrm{cm}^{-2}$ (Honkavaara et al. 2003). 
Manninen, M. et al. Silage digestibility and concentrate protein in feeding of bulls

\section{Economic evaluation}

The economic performance was determined by calculating the return on fixed inputs, or on inputs which were constant per day regardless of feeding strategy. In this examination, feeding cost and calf cost were considered as variable costs. The feeding cost varied because of diverse feed rations and feed prices. The treatment affected also the length of the finishing period and, thus, the calf cost per day. Market revenue and subsidies for beef production formed the gross return of the calculation. Since some premium payments are coupled to carcass weight, some to growing time (Niemi and Ahlsted 2008), the subsidies had to be included in the evaluation. The results are presented per day to allow for the varying length of the finishing period.

The unit prices and subsidy rates are shown in Table 1. The meat price expresses the price for meat in EUROP conformation R- and EUROP fat classification from 1 to 3 . One step downwards or upwards in the conformation results in a $0.10 € \mathrm{~kg}^{-1}$ decrease or increase of the price, respectively. Fat classification 4 or 5 causes a 0.30 and $0.60 € \mathrm{~kg}^{-1}$ decrease of the price, respectively. The meat price is graded by carcass weight and calf price increases with LW (M. Ilola, Atria, Seinäjoki, Finland; personal communication). The subsidy rates represent the subsidy level in Central Finland (subsidy area C2).

Barley, CPC and mineral mixture were priced at the market prices for May 2009. A milling cost of $0.016 € \mathrm{~kg}^{-1}$ was added to the market price of barley (ProAgria 2009a). The price of silage was set according to its production cost, $1.123 € \mathrm{ha}^{-1}$ when the subsidies paid ha-1 were subtracted from the total cost (ProAgria 2009a). Storage losses were estimated to be $15 \%$ (McDonald et al. 1991) and feeding losses $5 \%$ referring to the intended excess level of 1.05 in the feeding of silage.

A correlation between the harvesting time and yield of silage was considered while calculating the unit cost of E and L. Experiments undertaken in Central Finland in summer 2008 were used as a basic guideline in estimating the yield differences of varying cutting times (Vanhanen 2009). Using $100 \mathrm{~kg} \mathrm{~N} \mathrm{ha}^{-1}$ as a reference fertilizing level, the later harvesting of silage produced a $24 \%$ higher $\mathrm{DM}$ yield $\mathrm{ha}^{-1}$ than the earlier harvest. As those experimental yields were fairly high compared to yields in farm conditions, the observed relative yield difference was transferred to two lower yield

Table 1. Input prices, meat prices and subsidy rates for beef production in 2009.

\begin{tabular}{|c|c|c|c|}
\hline & Weight limits & Unit & Euro \\
\hline Silage, early-cut & & $€ \mathrm{~kg}^{-1} \mathrm{DM}$ & 0.144 \\
\hline Silage, late-cut & & $€ \mathrm{~kg}^{-1} \mathrm{DM}$ & 0.116 \\
\hline Barley & & $€ \mathrm{~kg}^{-1} \mathrm{DM}$ & 0.134 \\
\hline Commercial protein compound & & $€ \mathrm{~kg}^{-1} \mathrm{DM}$ & 0.295 \\
\hline Mineral mixture & & $€ \mathrm{~kg}^{-1} \mathrm{DM}$ & 0.567 \\
\hline Calf & live weight $140 \mathrm{~kg}$ & $€$ calf $^{-1}$ & 365.00 \\
\hline Calf & live weight $141-300 \mathrm{~kg}$ & $+€ \mathrm{~kg}^{-1}$ & 2.20 \\
\hline Calf & live weight $>300 \mathrm{~kg}$ & $+€ \mathrm{~kg}^{-1}$ & 1.30 \\
\hline Meat & carcass weight $290-319 \mathrm{~kg}$ & $€ \mathrm{~kg}^{-1}$ & 2.83 \\
\hline Meat & carcass weight $320-349 \mathrm{~kg}$ & $€ \mathrm{~kg}^{-1}$ & 2.89 \\
\hline Meat & carcass weight $\geq 350 \mathrm{~kg}$ & $€ \mathrm{~kg}^{-1}$ & 2.91 \\
\hline Special beef premium & & $€$ bull $^{-1}$ & 157.50 \\
\hline Slaughtered bull premium & carcass weight $\geq 330 \mathrm{~kg}$ & $€$ / slaughtered bull & 30.30 \\
\hline National aid & & $€ /$ livestock unit a / year & 422.00 \\
\hline
\end{tabular}

${ }^{a}$ bull older than 6 months and younger than 2 years equals 0.6 livestock unit 
Vol. 20(2011): 151-168.

levels. A yield level of $8700 \mathrm{~kg} \mathrm{DM} \mathrm{ha}{ }^{-1}$, which the best quarter of farmers are able to produce (ProAgria 2009b), was assumed in the basic solution. The other solution was based on an average yield, $6000 \mathrm{~kg} \mathrm{DM} \mathrm{ha}{ }^{-1}$ (ProAgria 2009b). The two levels were used to test the sensitivity of economic results with respect to silage price. Based on the results of Kuoppala et al. (2008), the effects of a change in the price difference between $\mathrm{E}$ and L were also analysed. Moreover, the sensitivity analysis concerned changes in the price of grain and meat and a reduction in subsidies.

\section{Statistical analysis}

Diet digestibility, daily intake, feed conversion (ratio of DM, ME, CP and AAT intake and $\mathrm{kg}$ net weight gain) and the ratio of DMI and $\mathrm{kg}^{-1} \mathrm{LW}^{0.75}$ were measured at the group level only and one-way analysis of variance was used to analyse the data. The rest of the variables were measured individually. Because treatments were assigned to groups, group was used as an error term when treatments were compared. The statistical model used in these analyses was:

$$
\mathrm{y}_{\mathrm{ijk} \mathrm{l}}=\mu+\varphi_{1}+\alpha_{\mathrm{i}}+\beta_{\mathrm{ijj} 1}+\varepsilon_{\mathrm{ijk} 1}
$$

where $y_{\mathrm{ijkl}}$ is the observed value of the response variable for the $\mathrm{k}^{\text {th }}$ animal in the $\mathrm{i}^{\text {th }}$ treatment in the $\mathrm{j}^{\text {th }}$ group, $\mu$ is the overall mean, $\alpha_{i}$ is the effect of the $i^{\text {th }}$ treatment, $\beta_{\mathrm{ij} 1}$ is the effect of group, $\varphi_{1}$ is the blocking effect for groups and $\mathrm{g}_{\mathrm{ijkl}}$ is the residual error. Animals were divided to groups according to animals' age at the start of the study (youngest - oldest) and blocking effect takes into account this. The effect of $\alpha_{i}$ was divided into three parts: main effect of silage digestibility, main effect of concentrate protein concentration and their interaction. Statistical analyses were carried out using the SAS/GLM software (SAS 2004).

SAS/MIXED software was used only for economic variables. In the SAS/MIXED analyses the effect of group was used as a normally distributed random effect. MIXED analysis was rejected for the analysis of the non-economic variables, be- cause the estimated variance for group effect was not positive for most variables.

\section{Results}

\section{Feeds}

The DM, CP and D values of the sward pre-samples were 191, 228 and $212 \mathrm{~g} \mathrm{~kg}^{-1}, 182,162$ and $137 \mathrm{~g} \mathrm{~kg}^{-1}$ $\mathrm{DM}$ and 763,755 and $740 \mathrm{~g} \mathrm{~kg}^{-1} \mathrm{DM}$, respectively. The red clover content of the sward varied from 15 to $20 \%$ in DM with no difference between $\mathrm{E}$ and $\mathrm{L}$. The $\mathrm{D}$ values for silages $\mathrm{E}$ and $\mathrm{L}$ averaged 750 and $699 \mathrm{~g} \mathrm{~kg}^{-1} \mathrm{DM}$, respectively. The contents of DM, ash, NDF, WSC as well as pH and ammonia and soluble $\mathrm{N}$ in total $\mathrm{N}$ were higher in $\mathrm{L}$ than in E (Table 2).

\section{Diet digestibility and feed intake}

The digestibility of diet OM was lower $(p<0.05$, 0.733 vs. 0.769 ) and the digestibility of diet protein tended to be lower ( $p<0.10,0.667$ vs. 0.697$)$ on diet $\mathrm{L}$ than on diet $\mathrm{E}$ (Table 3 ). The digestibility of diet NDF was lower ( $p<0.05,0.625$ vs. 0.665$)$ on diet $\mathrm{L}$ than on diet $\mathrm{E}$ and tended to be lower $(p$ $<0.10,0.631$ vs. 0.660 ) on diet $\mathrm{M}$ than on $\operatorname{diet} \mathrm{H}$.

During the entire experiment the daily intake of concentrate was almost identical on all diets as expected due to the fixed feeding regimens averaging $3.17 \mathrm{~kg}$ DM and including 0.452 and $1.129 \mathrm{~kg}$ of rapeseed cake in $\mathrm{M}$ and $\mathrm{H}$, respectively (Table 4). No refusals of milled barley or pelleted CPC were observed due to the moderate amounts of both feeds offered, maximum $4.0 \mathrm{~kg} \mathrm{DM}$ daily pre-slaughter (P3). Treatments had no effect on the daily intake of GCS, the total intake of DM, OM, DMI kg-1 $\mathrm{LW}^{0.75}$ and ME averaging 6.0, 9.4 and $8.6 \mathrm{~kg} \mathrm{DM}, 97.4 \mathrm{~g}$ and $109.4 \mathrm{MJ}$, respectively. The daily intake of CP was $65 \mathrm{~g}$ lower $(p<0.05)$ on diet L compared with diet $\mathrm{E}$ and $158 \mathrm{~g}$ lower $(p$ $<0.01)$ on diet $\mathrm{M}$ compared with diet $\mathrm{H}$. The daily 
Manninen, M. et al. Silage digestibility and concentrate protein in feeding of bulls

Table 2. Harvests of grass-red clover silages and mean chemical compositions and feed values of experimental feeds.

\begin{tabular}{|c|c|c|c|c|c|c|c|}
\hline & $\begin{array}{l}\text { Silage, } \\
\text { Early-cut } \\
\text { Mean }\end{array}$ & $\mathrm{SD}^{\mathrm{a}}$ & $\begin{array}{l}\text { Silage, } \\
\text { Late-cut } \\
\text { Mean }\end{array}$ & SD & Barley & $\begin{array}{l}\text { Commercial } \\
\text { protein } \\
\text { compound }\end{array}$ & $\begin{array}{l}\text { Mineral } \\
\text { mixture }\end{array}$ \\
\hline Harvest date & 17-18 June & & 31 June-1 July & & & & \\
\hline Growing time $^{\mathrm{b}},(\mathrm{d})$ & 42 & & 55 & & & & \\
\hline Degree days ${ }^{\mathrm{b}},\left({ }^{\circ} \mathrm{C}\right)$ & 256 & & 354 & & & & \\
\hline Number of samples & 4 & & 4 & & 1 & 1 & 1 \\
\hline Dry matter (DM, $\left.\mathrm{g} \mathrm{kg}^{-1}\right)$ & 251 & 44 & 307 & 22.4 & 879 & 881 & 968 \\
\hline \multicolumn{8}{|l|}{ In DM $\left(\mathrm{g} \mathrm{kg}^{-1}\right)$} \\
\hline Ash & 76 & 2 & 85 & 3.8 & 29 & 88 & 550 \\
\hline Crude protein & 162 & 19.9 & 151 & 7.4 & 143 & 289 & 67 \\
\hline Ether extract & $\mathrm{nd}^{\mathrm{c}}$ & & nd & & 20 & 84 & nd \\
\hline Crude fibre & nd & & nd & & 55 & 121 & nd \\
\hline Neutral detergent fibre & 418 & 4.3 & 483 & 11.6 & 226 & 313 & 97 \\
\hline Lactic acid & 73 & 4.8 & 45 & 10 & & & \\
\hline Acetic acid & 28 & 2.5 & 18 & 3.4 & & & \\
\hline Butyric acid & 0.4 & 0.388 & 0.38 & 0.573 & & & \\
\hline Ethanol & 8 & 4.21 & 4.4 & 0.94 & & & \\
\hline Water-soluble carbohydrates & 26 & 11.1 & 52 & 25.2 & & & \\
\hline $\mathrm{pH}$ & 3.78 & 0.116 & 4.03 & 0.075 & & & \\
\hline \multicolumn{8}{|l|}{ In total nitrogen $\left(\mathrm{g} \mathrm{kg}^{-1}\right)$} \\
\hline Ammonia $\mathrm{N}$ & 40 & 5.7 & 45 & 3.1 & & & \\
\hline Soluble N & 511 & 69 & 547 & 43.9 & & & \\
\hline D value ${ }^{\mathrm{d}}, \mathrm{g} \mathrm{kg}^{-1} \mathrm{DM}$ & 750 & 4.4 & 699 & 10.2 & & & \\
\hline Intake index & 108 & 1.4 & 103 & 1.8 & & & \\
\hline \multicolumn{8}{|l|}{ Feed value, $\mathrm{kg}^{-1} \mathrm{DM}$} \\
\hline Metabolizable energy, MJ & 12 & 0.07 & 11.2 & 0.16 & 13.1 & 11.9 & \\
\hline $\mathrm{AAT}^{e}, \mathrm{~g}$ & 91 & 1.1 & 86 & 0.5 & 107 & 137 & \\
\hline
\end{tabular}

${ }^{\mathrm{a}}$ Standard deviation.

${ }^{\mathrm{b}}$ Calculated from the beginning of growing season on 6 May 2003.

${ }^{\mathrm{c}}$ Not determined.

${ }^{\mathrm{d}}$ Digestible organic matter in dry matter.

e Amino acids absorbed in the small intestine.

Table 3. Mean treatment effects on in vivo dietary digestibility coefficients.

\begin{tabular}{|c|c|c|c|c|c|c|c|c|}
\hline \multirow{2}{*}{$\begin{array}{l}\text { Silage digestibility }(\mathrm{S}) \\
\text { Concentrate protein concentration }(\mathrm{P})\end{array}$} & \multicolumn{2}{|c|}{ Early-cut } & \multicolumn{2}{|c|}{ Late-cut } & \multirow[b]{2}{*}{ SEM $^{a}$} & \multicolumn{3}{|c|}{ Significance $^{\mathrm{b}}$} \\
\hline & Medium & High & Medium & High & & $\mathrm{S}$ & $P$ & $\mathrm{~S} \times \mathrm{P}$ \\
\hline Number of groups & 2 & 2 & 2 & 2 & & & & \\
\hline Organic matter & 0.766 & 0.773 & 0.734 & 0.732 & 0.0067 & * & & \\
\hline Protein & 0.691 & 0.703 & 0.656 & 0.677 & 0.0104 & o & & \\
\hline Neutral detergent fibre & 0.642 & 0.688 & 0.619 & 0.632 & 0.0112 & * & o & \\
\hline
\end{tabular}

a SEM $=$ standard error of mean.

${ }^{\mathrm{b}}$ o $p<0.10 ; * p<0.05 ; * * p<0.01 ; * * * p<0.001$. 
Vol. 20(2011): 151-168.

Table 4. Mean daily intakes on experimental diets.

\begin{tabular}{|c|c|c|c|c|c|c|c|c|}
\hline \multirow{2}{*}{$\begin{array}{l}\text { Silage digestibility }(\mathrm{S}) \\
\text { Concentrate protein concentration }(\mathrm{P})\end{array}$} & \multicolumn{2}{|c|}{ Early-cut } & \multicolumn{2}{|c|}{ Late-cut } & \multirow[b]{2}{*}{$\mathrm{SEM}^{\mathrm{a}}$} & \multicolumn{3}{|c|}{ Significance $^{b}$} \\
\hline & Medium & High & Medium & High & & $\mathrm{S}$ & $\mathrm{P}$ & $\mathrm{S} \times \mathrm{P}$ \\
\hline Number of groups & 2 & 2 & 2 & 2 & & & & \\
\hline \multicolumn{9}{|l|}{ Dry matter, kg } \\
\hline Grass-red clover silage & 5.88 & 5.98 & 5.86 & 6.13 & 0.157 & & & \\
\hline Concentrate $^{c}$ & 3.13 & 3.16 & 3.2 & 3.2 & 0.014 & $n t^{d}$ & $\mathrm{nt}$ & $\mathrm{nt}$ \\
\hline Mineral mixture & 0.28 & 0.29 & 0.28 & 0.28 & 0.001 & $\mathrm{nt}$ & nt & $\mathrm{nt}$ \\
\hline Total & 9.30 & 9.43 & 9.34 & 9.61 & 0.149 & & & \\
\hline Dry matter, $\mathrm{g} \mathrm{kg}^{-1} \mathrm{LW}^{0.75}$ & 95.8 & 96.2 & 98.0 & 99.8 & 1.39 & & & \\
\hline Organic matter, $\mathrm{kg}$ & 8.58 & 8.64 & 8.57 & 8.76 & 0.137 & & & \\
\hline Metabolizable energy, MJ & 110.9 & 111.4 & 106.7 & 108.7 & 1.69 & & & \\
\hline Crude protein, $\mathrm{g}$ & 1518 & 1666 & 1443 & 1611 & 19.8 & $*$ & $* *$ & \\
\hline $\mathrm{AAT}^{\mathrm{e}}, \mathrm{g}$ & 890 & 928 & 862 & 911 & 12.6 & & $*$ & \\
\hline Neutral detergent fibre, $g$ & 3250 & 3372 & 3637 & 3842 & 72.1 & $* *$ & & \\
\hline
\end{tabular}

a SEM $=$ standard error of mean.

bo $p<0.10 ; * p<0.05 ; * * p<0.01 ; * * * p<0.001$.

'Concentrate: Including barley and commercial protein compound.

${ }^{\mathrm{d}}$ Not tested.

${ }^{\mathrm{e} A m i n o}$ acids absorbed in the small intestine.

intake of AAT was $43 \mathrm{~g}$ higher $(p<0.05)$ on $\operatorname{diet} \mathrm{H}$ than on diet M. The daily intake of NDF was $429 \mathrm{~g}$ higher $(p<0.01)$ on diet $\mathrm{L}$ than on diet $\mathrm{E}$.

The proportion of concentrate in the total daily DMI averaged 0.337 during the entire experiment. The proportion of CP and NDF in the total daily DMI on diets EM, EH, LM and LH were 0.163 , $0.177,0.155$ and 0.168 , and $0.350,0.358,0.389$ and 0.400 , respectively.

\section{Animal growth and feed conversion}

The health of the animals was good and no signs of diseases were observed. The concentrate protein concentration had no effects on animal performance (Table 5). The duration of the entire experiment was on average 18 days longer $(p<0.01)$ on diet $\mathrm{L}$ compared with diet $\mathrm{E}$. The final $\mathrm{LW}$ was as planned equal for all animals, averaging $606 \mathrm{~kg}$. During the entire experiment the LWG and the net weight gain were on average $187(p<0.01)$ and $116 \mathrm{~g} \mathrm{~d}^{-1}$ $(p<0.05)$ higher on diet $\mathrm{E}$ compared with diet L. The animals on diet $\mathrm{E}$ tended to consume daily on average $1.29 \mathrm{~kg}$ less DM $(p<0.10) \mathrm{kg}^{-1}$ net weight gain than those on diet L. The daily consumption of CP, ME and AAT kg-1 net weight gain was on average $1614 \mathrm{~g}, 113.3 \mathrm{MJ}$ and $930 \mathrm{~g}$, respectively.

\section{Carcass and meat evaluation}

The treatments had no significant effect on the killout proportion, carcass conformation and carcass fat classification which averaged $537 \mathrm{~g} \mathrm{~kg}^{-1}, 6.5$ and 3.6 , respectively (Table 5), or on the juiciness and shear force value of the meat which averaged 4.5 and $4.3 \mathrm{~kg} \mathrm{~cm}^{-2}$, respectively (Table 6 ). The taste of meat $\mathrm{L}$ tended to be better than that of meat E ( $p<$ $0.10,4.9$ vs. 4.4$)$. In $\mathrm{pH}$ and sensory evaluation of tenderness there were significant interactions $(p<$ 0.05 ) between silage digestibility and concentrate protein concentration. The tenderness was better and the $\mathrm{pH}$ lower in meat EM compared with meat $\mathrm{EH}$ with the opposite being true in meat L. Normal $\mathrm{pH}$ values of beef are from 5.50 to 5.90 a day after slaughter. On diet EM, three meat samples had a very low $\mathrm{pH}$ value $(\leq 5.50)$. Correspondingly, on 


\section{AGRICULTURAL AND FOOD SCIENCE}

\section{Manninen, M. et al. Silage digestibility and concentrate protein in feeding of bulls}

Table 5. Age of animals, duration of the experiment, live weights, live and net weight gains, slaughter data and feed conversion.

\begin{tabular}{|c|c|c|c|c|c|c|c|}
\hline \multirow{2}{*}{$\begin{array}{l}\text { Silage digestibility }(\mathrm{S}) \\
\text { Concentrate protein concentration }(\mathrm{P})\end{array}$} & \multicolumn{2}{|c|}{ Early-cut } & \multicolumn{3}{|c|}{ Late-cut } & \multicolumn{2}{|c|}{ Significance $^{b}$} \\
\hline & Medium & High & Medium & High & SEM $^{\mathrm{a}}$ & $\mathrm{S}$ & $\mathrm{P} \quad \mathrm{S} \times \mathrm{P}$ \\
\hline Number of animals & 8 & 8 & $7^{\mathrm{c}}$ & 8 & & & \\
\hline \multicolumn{8}{|l|}{ Age, d } \\
\hline Initial & 229 & 215 & 232 & 225 & 6.5 & & \\
\hline At end of experiment & 407 & 395 & 430 & 420 & 7.5 & o & \\
\hline Duration of the experiment, $d$ & 179 & 179 & 198 & 195 & 1.8 & $* *$ & \\
\hline \multicolumn{8}{|l|}{ Live weight, $\mathrm{kg}$} \\
\hline Initial & 288 & 288 & 287 & 288 & 0.4 & & \\
\hline Final & 604 & 610 & 601 & 606 & 3.8 & & \\
\hline Live weight gain, $\mathrm{g} \mathrm{d}^{-1}$ & 1782 & 1809 & 1588 & 1630 & 22.1 & $* *$ & \\
\hline Net weight gain ${ }^{\mathrm{d}}, \mathrm{g} \mathrm{d}^{-1}$ & 1009 & 1048 & 902 & 923 & 20.2 & $*$ & \\
\hline \multicolumn{8}{|l|}{ Slaughter data } \\
\hline Carcass weight, $\mathrm{kg}$ & 324 & 331 & 321 & 324 & 4.1 & & \\
\hline Kill-out ${ }^{\mathrm{e}}, \mathrm{g} \mathrm{kg}^{-1}$ & 0.536 & 0.543 & 0.535 & 0.535 & 0.0038 & & \\
\hline EUROP conformation ${ }^{\mathrm{f}}$ & 6.5 & 6.6 & 6 & 6.6 & 0.34 & & \\
\hline EUROP fat classification ${ }^{\mathrm{g}}$ & 3.5 & 3.6 & 3.3 & 3.9 & 0.17 & & \\
\hline \multicolumn{8}{|l|}{ Feed conversion, $\mathrm{kg}^{-1}$ net weight gain ${ }^{\mathrm{h}}$} \\
\hline Dry matter, kg & 9.24 & 9.01 & 10.36 & 10.46 & 0.576 & o & \\
\hline Metabolizable energy, MJ & 110.2 & 106.5 & 118.3 & 118.3 & 6.57 & & \\
\hline Crude protein, $\mathrm{g}$ & 1508 & 1592 & 1600 & 1754 & 95.8 & & \\
\hline $\mathrm{AAT}^{\mathrm{i}}, \mathrm{g}$ & 884 & 886 & 956 & 992 & 52.3 & & \\
\hline
\end{tabular}

${ }^{a} \mathrm{SEM}=$ standard error of mean.

${ }^{\mathrm{b}}$ o $p<0.10 ; * p<0.05 ; * * p<0.01 ; * * * p<0.001$.

${ }^{c}$ The SEM given should be multiplied by 1.0801 when making comparisons with other means except for feed conversion

${ }^{\mathrm{d}}$ Kill-out proportion of 50 used for calculation of net weight gain.

${ }^{\text {e }}$ Ratio of cold carcass weight to final live weight.

${ }^{\mathrm{f}}$ Conformation: $\mathrm{O}-=4, \mathrm{O}=5, \mathrm{O}+=6, \mathrm{R}-=7, \mathrm{R}=8, \mathrm{R}+=9$.

${ }^{\mathrm{g}}$ Fat cover: $1=$ leanest, $\ldots, 5=$ fattest.

${ }^{\mathrm{h}}$ Two groups per treatment.

${ }^{\mathrm{i}} \mathrm{AAT}=$ Amino acids absorbed in the small intestine.

Table 6. Loin sensory evaluation, shear force value and $\mathrm{pH}$.

\begin{tabular}{|c|c|c|c|c|c|c|c|c|}
\hline \multirow{2}{*}{$\begin{array}{l}\text { Silage digestibility }(\mathrm{S}) \\
\text { Concentrate protein concentration }(\mathrm{P})\end{array}$} & \multicolumn{2}{|c|}{ Early-cut } & \multicolumn{2}{|c|}{ Late-cut } & \multirow[b]{2}{*}{ SEM $^{\mathrm{a}}$} & \multicolumn{3}{|c|}{ Significance $^{b}$} \\
\hline & Medium & High & Medium & High & & $\mathrm{S}$ & $\mathrm{P}$ & $\mathrm{S} \times \mathrm{P}$ \\
\hline Number of samples & 8 & $8^{c}$ & $7^{\mathrm{d}}$ & 8 & & & & \\
\hline \multicolumn{9}{|l|}{ Sensory evaluation ${ }^{\mathrm{e}}$} \\
\hline Tenderness & 5.6 & 5.1 & 5.2 & 5.9 & 0.13 & & & $*$ \\
\hline Juiciness & 4.5 & 4.3 & 4.7 & 4.8 & 0.23 & & & \\
\hline Taste & 4.8 & 4.1 & 4.9 & 5.0 & 0.17 & o & & \\
\hline Shear force value, $\mathrm{kg} \mathrm{cm}^{-2}$ & 4.4 & 4.6 & 4.2 & 4.1 & 0.23 & & & \\
\hline $\mathrm{pH}$ & 5.52 & 5.59 & 5.57 & 5.54 & 0.011 & & & $*$ \\
\hline
\end{tabular}

${ }^{\mathrm{a}} \mathrm{SEM}=$ standard error of mean.

${ }^{\mathrm{b}} \mathrm{o} p<0.10 ; * p<0.05 ; * * p<0.01 ; * * * p<0.001$.

${ }^{\mathrm{c}} \mathrm{N}=7$ for $\mathrm{pH}$.

d The S.E.M. given should be multiplied by 1.0801 when making comparisons with other means.

${ }^{\text {e }}$ Sensory evaluation: Scale from 1 to 7. 
Vol. 20(2011): 151-168.

diets EH, LM and LH, two, one and one samples had a very low $\mathrm{pH}$ value. On diet EM, the minimum and maximum $\mathrm{pH}$ values were 5.40 and 5.62, respectively. The corresponding values on diets $\mathrm{EH}$, LM and LH were 5.48 and 5.75, 5.42 and 5.73 and 5.38 and 5.62, respectively. Thus, all $\mathrm{pH}$ values were below 6.00 .

On diet EM, two meat samples were recorded as being slightly dry and one dry with slight offflavour. Two samples had liver flavour, one was tasteless and another dry on diet EH. On diet LM, one sample was slightly dry and one had liver flavour. Two samples had off-flavour and one was dry on diet LH.

The treatments had no significant effect on the amount $(\mathrm{kg})$ and yield (\%) of inside round, roast beef, loin, tenderloin and tallow in a carcass, averaging $11.5,5.6,10.3,4.0$ and $34.5 \mathrm{~kg}$ and 3.5 , $1.7,3.2,1.2$ and $10.6 \%$, respectively (Table 7 ). The amount and yield of outside round tended to be higher ( $p<0.10,18.2$ vs. $17.5 \mathrm{~kg}$ and 5.6 vs. $5.4 \%)$ on carcasses fed diet $\mathrm{E}$ than diet $\mathrm{L}$. The amount of corner round was higher ( $p<0.05,10.6$ vs. 10.1 $\mathrm{kg}$ ) on carcasses fed diet $\mathrm{E}$ than diet L. The amount of valuable cuttings tended to be higher $(p<0.10$, 100.9 vs. $98.6 \mathrm{~kg}$ ) on carcasses fed diet $\mathrm{E}$ than diet L.

\section{Economic performance}

The results of the economic analysis (Table 8) indicated that the diet EH caused the highest feed cost per day $(p<0.001)$. A reason for this was the highest unit cost of feed since the daily DMI was unaffected by the diet (Table 4). Carcass weights, carcass conformation and carcass fat classification

Table 7. Valuable cuts of the animals.

\begin{tabular}{|c|c|c|c|c|c|c|c|c|}
\hline \multirow{2}{*}{$\begin{array}{l}\text { Silage digestibility }(\mathrm{S}) \\
\text { Concentrate protein concentration }(\mathrm{P})\end{array}$} & \multicolumn{2}{|c|}{ Early-cut } & \multicolumn{2}{|c|}{ Late-cut } & \multirow[b]{2}{*}{ SEM $^{\mathrm{a}}$} & \multicolumn{3}{|c|}{ Significance $^{\mathrm{b}}$} \\
\hline & Medium & High & Medium & High & & $\mathrm{S}$ & $\mathrm{P}$ & $\mathrm{S} \times \mathrm{P}$ \\
\hline Number of animals & 8 & 8 & $7^{\mathrm{c}}$ & 8 & & & & \\
\hline Outside round, $\mathrm{kg}$ & 18.1 & 18.3 & 17.4 & 17.7 & 0.24 & o & & \\
\hline From yield, \% & 5.6 & 5.5 & 5.3 & 5.5 & 0.06 & o & & \\
\hline Inside round, $\mathrm{kg}$ & 11.8 & 11.6 & 11.1 & 11.4 & 0.40 & & & \\
\hline From yield, \% & 3.6 & 3.5 & 3.4 & 3.5 & 0.07 & & & \\
\hline Corner round, $\mathrm{kg}$ & 10.7 & 10.5 & 10.1 & 10.2 & 0.09 & $*$ & & \\
\hline From yield, \% & 3.3 & 3.2 & 3.1 & 3.1 & 0.04 & o & & o \\
\hline Roast beef, kg & 5.5 & 5.9 & 5.5 & 5.4 & 0.21 & & & \\
\hline From yield, \% & 1.7 & 1.8 & 1.7 & 1.7 & 0.06 & & & \\
\hline Loin, kg & 10.5 & 10.0 & 10.3 & 10.4 & 0.38 & & & \\
\hline From yield, \% & 3.2 & 3.0 & 3.2 & 3.2 & 0.06 & & & \\
\hline Tenderloin, kg & 4.1 & 4.0 & 3.9 & 3.9 & 0.11 & & & \\
\hline From yield, \% & 1.3 & 1.2 & 1.2 & 1.2 & 0.02 & & & \\
\hline Tallow, kg & 35.2 & 33.7 & 33.4 & 35.4 & 0.83 & & & \\
\hline From yield, \% & 10.9 & 10.1 & 10.2 & 10.9 & 0.40 & & & \\
\hline Yield from carcass weight, $\mathrm{kg}$ & 101.5 & 100.2 & 97.2 & 100.0 & 0.88 & o & & \\
\hline Yield from carcass weight, $\%$ & 31.4 & 30.2 & 29.8 & 30.9 & 0.37 & & & o \\
\hline
\end{tabular}


Manninen, M. et al. Silage digestibility and concentrate protein in feeding of bulls

caused some variation in the meat price, but the differences between the diets were not statistically significant. However, the diet $\mathrm{E}$ resulted in slightly higher market revenue per day than the diet L $(p<$ 0.10 ) because of a higher LWG per day and, thus, a shorter finishing period to reach the targeted carcass weight (Table 6). The premiums paid per animal decreased with the length of the finishing period and, therefore, the subsidies per day were slightly higher on diet $\mathrm{E}$ than on diet $\mathrm{L}(p<0.10)$. Also the calf cost per day decreased, as expected, with the length of the finishing period, but not statistically significantly.

As the fluctuations in costs and returns cancelled each other out, the average return on the fixed inputs was nearly the same on all the diets. No statistically significant differences were found although the average return of diet LH was some lower than the returns of other diets. Sensitivity analysis revealed the stability of the results. Most of the analysed price changes did not change the ranking of the treatments; they just affected the lev$\mathrm{el}$ of the return on fixed inputs. Increase of $0.05 €$ $\mathrm{kg}^{-1} \mathrm{DM}(\mathrm{L})$ and $0.06 € \mathrm{~kg}^{-1} \mathrm{DM}(\mathrm{E})$ in the unit cost of silage would decrease the return on fixed inputs by $0.46 € \mathrm{~d}^{-1}(E)$ and $0.37 € \mathrm{~d}^{-1}(\mathrm{~L})$. A smaller price difference $(19 \%)$ between $\mathrm{E}$ and $\mathrm{L}$ would result in about $0.02 € \mathrm{~d}^{-1}$ higher (E) or lower (L) return on fixed inputs compared to the basic solution where the difference was $24 \%$. A rise of $30 \%$ in the price of grain would cause a reduction in the return on fixed inputs ranging between $0.05 € \mathrm{~d}^{-1}(\mathrm{LM})$ and $0.10 € \mathrm{~d}^{-1}(\mathrm{EM})$. Only LM with the cheapest feed cost would result in a positive return to fixed inputs if the meat price fell off by $20 \%$. Equal cutting of subsidies would not cause as dramatic drop in the return. The reduction would vary from $0.33 €$ $\mathrm{d}^{-1}(\mathrm{LH})$ to $0.36 € \mathrm{~d}^{-1}$ (EM and $\left.\mathrm{EH}\right)$. An increase of $20 \%$ in the basic price of meat would raise the return considerably, more than double on E. Such a price change would also mean that $\mathrm{E}$ would give a better economic result than $\mathrm{L}(p<0.10)$.

\section{Discussion}

\section{Feeds}

In the present study, a cold onset to the growing season delayed the decrease in the sward $\mathrm{D}$ value. In addition, the development of red clover is slower than that of grasses (Rinne and Nykänen 2000), which probably slightly affected the decrease in digestibility. In the present study, the daily decline

Table 8. Unit price of meat and feed, gross return, expenses and return on fixed inputs.

\begin{tabular}{|c|c|c|c|c|c|c|c|c|c|}
\hline \multirow{2}{*}{$\begin{array}{l}\text { Silage digestibility }(\mathrm{S}) \\
\text { Concentrate protein concentration }(\mathrm{P})\end{array}$} & & \multicolumn{2}{|c|}{ Early-cut } & \multicolumn{2}{|c|}{ Late-cut } & \multirow[t]{2}{*}{ SEM $^{\mathrm{a}}$} & \multicolumn{3}{|c|}{ Significance $^{b}$} \\
\hline & & Medium & High & Medium & High & & $\mathrm{S}$ & $\mathrm{P}$ & $\mathrm{S} * \mathrm{P}$ \\
\hline Number of groups & & 2 & 2 & 2 & 2 & & & & \\
\hline Meat price & $€ \mathrm{~kg}^{-1}$ & 2.690 & 2.665 & 2.700 & 2.575 & $0.0678-0.0703$ & & & \\
\hline Average feed price & $€ \mathrm{~kg}^{-1} \mathrm{DM}$ & 0.173 & 0.180 & 0.159 & 0.166 & 0.0053 & $*$ & o & \\
\hline \multicolumn{10}{|l|}{ Gross return } \\
\hline Market revenue & $€ \mathrm{~d}^{-1}$ & 4.82 & 4.98 & 4.32 & 4.20 & $0.321-0.331$ & $\circ$ & & \\
\hline Subsidies & $€ \mathrm{~d}^{-1}$ & 1.82 & 1.81 & 1.69 & 1.67 & $0.125-0.127$ & $\circ$ & & \\
\hline \multicolumn{10}{|l|}{ Expenses } \\
\hline Calf cost & $€ \mathrm{~d}^{-1}$ & 3.83 & 3.88 & 3.38 & 3.46 & $0.620-0.625$ & & & \\
\hline Feed cost & $€ \mathrm{~d}^{-1}$ & 1.81 & 1.91 & 1.67 & 1.80 & 0.006 & $* * *$ & $* * *$ & o \\
\hline Return on fixed inputs & $€ \mathrm{~d}^{-1}$ & 1.00 & 1.00 & 0.96 & 0.61 & $0.229-0.233$ & & & \\
\hline
\end{tabular}

${ }^{\text {aSEM }}=$ standard error of mean.

${ }^{\mathrm{b}}$ o $p<0.10 ; * p<0.05 ; * * p<0.01 ; * * * p<0.001$. 
Vol. 20(2011): 151-168.

from pre sampling to early cut was on average 1.9 $\mathrm{g} \mathrm{kg}^{-1} \mathrm{DM}$, and from early cut to late cut $3.6 \mathrm{~g} \mathrm{~kg}^{-1}$ DM. Because the swards were needed for grazing studies, the harvest had to be done at an earlier stage of maturity than planned, resulting in on average $50 \mathrm{~g} \mathrm{~kg}^{-1} \mathrm{DM}$ higher D values in the silages than originally planned.

The fermentation quality was good in both silages, while the DM content in $\mathrm{L}$ was higher than in E. The E silage was slightly more fermented including less WSC than the L silage. In both silages, the CP concentration was fairly typical for primary growth silage, but the content of NDF was quite low, probably due to the early stage of maturity and the inclusion of red clover in the silage (MTT 2006). The wilted silages did not freeze and were therefore suitable for this type of feeding in cold conditions. The last group of animals was slaughtered on 23 June, but the quality of silage remained acceptable in May and June.

\section{Effects of silage digestibility on animal performance}

The digestibility of the silage did not affect the DMI of the silage, corresponding to the results reported by Nadeau et al. (2002) and Cummins et al. (2007). The similar intake of both silages may be due to the high digestibility and good fermentation quality of both silages and, partly, due to the higher DM content of L compared with E. However, several studies with growing cattle (Steen 1988b, Martinsson 1990, Steen 1992, Scollan et al. 2001, Steen et al. 2002, Keady et al. 2008) have confirmed an increased intake of silage in response to higher digestibility. Aronen et al. (1992) observed earlycut grass silage to improve the LWG of light (initial LW $123 \mathrm{~kg}$ ) dairy-breed bulls during the first six months of growth but the bulls offered late-cut silage compensated the difference during the following six months pre-slaughter. This was mainly due to the larger grass silage intake of the early-cut bulls compared to the late-cut bulls. However, the difference between the harvest times of those silages was one week. Furthermore, Aronen et al. (1992) concluded that the bulls were not able to take full advantage of the high protein concentration (160 $\left.\mathrm{g} \mathrm{kg}^{-1} \mathrm{DM}\right)$ of the early-cut silage. In the present study, the CP concentration of $\mathrm{E}$ and $\mathrm{L}$ averaged 162 and $151 \mathrm{~g} \mathrm{~kg}^{-1} \mathrm{DM}$. Thus, the difference in the $\mathrm{CP}$ concentration of silages was small compared with a big difference in $\mathrm{D}$ value.

As in the present study, in several studies with growing cattle and sheep, postponing the harvest of silage has reduced the digestibility of silage as a sole feed (Drennan and Keane 1987, Dawson et al. 2002, Keady et al. 2008) or the digestibility of diets (Steen 1988b, Martinsson 1990, Steen 1992, Scollan et al. 2001). Harvest date is the major factor effecting silage digestibility.

In the present study, the calculated ME intake was similar on all the diets and thus did not explain the difference in the growth rate. The growth rate can be considered as very high for all animals. Steen et al. (2002) concluded that high-digestibility (0.743 DOM in DM) silage had potential relative to high-concentrate diet. It can be assumed that the main reason for the very high growth rate in the present study was the effect of high silage digestibility leading to high energy intake and optimal conditions for microbial protein synthesis in the rumen. According to Schroeder and Titgemeyer (2008), energy supply affects the efficiency of protein utilization. The improved LWG on early-cut silage or on silage of high digestibility has earlier been confirmed in several studies (e.g. Scollan et al. 2001, Nadeau et al. 2002, Steen et al. 2002, Keady et al. 2008), but also opposing results exist (Steen 1988b, Cummins et al. 2007). In a review of literature, Steen (1988a) summarized that in 11 comparisons of unsupplemented silages, increasing digestibility increased daily LWG and carcass gain of finishing cattle by 45 and $33 \mathrm{~g}$, respectively, per $10 \mathrm{~g} \mathrm{~kg}^{-1}$ increase in digestibility. In eight comparisons in which the silages were supplemented with concentrates (20 to $37 \%$ of total DMI), increasing digestibility increased daily LW and carcass gains by 37 and $28 \mathrm{~g}$, respectively, per $10 \mathrm{~g} \mathrm{~kg}^{-1}$ increase in digestibility. In the present study, daily LWG and carcass gain were increased by 37 and $23 \mathrm{~g}$ per $10 \mathrm{~g} \mathrm{~kg}^{-1}$ increase in silage digestibility, well in agreement with Steen (1988a). 
Manninen, M. et al. Silage digestibility and concentrate protein in feeding of bulls

The silage digestibility had no effect on the killout proportion and the carcass fat and conformation scores were in accordance with earlier studies (Steen 1988b, Cummins et al. 2007). In some experiments, high digestible silage has increased carcass fatness (Drennan and Keane 1987, Steen et al. 2002, Keady et al. 2008). The varying responses to silage digestibility may be due to differences in silage digestibility, final LW, breed, breed maturity, gender and proportion of concentrate in the diet.

When Hf bulls were offered concentrate, either restricted or ad libitum, and grass silage (D value $700 \mathrm{~g} \mathrm{~kg}^{-1} \mathrm{DM}$ ) ad libitum for three months pre-slaughter, $35 \%$ of the carcasses had a fat score of 5, without treatment effects (Manninen et al. 2010). Those carcasses were approximately $30 \mathrm{~kg}$ heavier than the carcasses in the present study. The results of the present study and those observed by Manninen et al. (2010) agree with Steen and Kilpatrick (2000) who concluded that for cattle reared on high-forage diets, reducing slaughter weight is likely to be a more effective approach to reduce carcass fat content than reducing energy intake during the finishing period.

\section{Effects of concentrate protein concentra- tion on animal performance}

The concentrate protein concentration did not affect the intake of silage and total DMI kg-1 metabolic LW, which was consistent with the results observed with heavy dairy-breed bulls (Huuskonen 2009a). Additionally, in earlier studies with suckled continental-cross bulls (Drennan et al. 1994) or heavy steers (Steen 1988b, Steen 1996a), silage intake was unaffected by protein supplement. On the contrary, rapeseed meal supplementation increased the silage (Aronen 1990, Aronen et al. 1992) intake of light dairy-breed bulls. The positive response of intake to protein supplement may be more evident in animals of lower LW than in the bulls in the present study, as also Aronen (1990) suggested.

The digestibility of dietary OM was unaffected by concentrate protein concentration, in accordance with Huuskonen et al. $(2007,2008)$ and $\mathrm{Hu}-$ uskonen (2009a). In numerous studies (e.g. Steen 1988b, Huuskonen et al. 2007, 2008, Huuskonen 2009a), protein supplement increased the digestibility of dietary protein, which was not observed in this study.

The growth response to protein supplementation depends generally on animal LW, silage digestibility, proportion of concentrate in the diet and breed. If the supply of energy is good, the microbial protein synthesis is generally sufficient to sustain a high LWG in animals of a LW over $250 \mathrm{~kg}$ (Huuskonen 2009b). Titgemeyer and Löest (2001) presented that, while amino acids were the limiting factor with lighter calves offered grass silage, energy availability was the limiting factor with heavier animals. Later, Schroeder and Titgemeyer (2008) concluded that energy supply affects the efficiency of protein utilization but the effects may be different, depending on which amino acid is the most limiting. In the present study, the supply of energy was sufficient with a diet with a moderate amount of concentrate and high-digestibility silage. Waterhouse et al. (1985) reported that Friesian steers were most likely to respond to supplementary protein in barley-based concentrate when the grass silage in vitro digestibility was below 0.65 . In the present study, there was no benefit from the higher concentrate protein concentration, suggesting that the amino acid supply from feed protein and microbial protein synthesis in the rumen was sufficient on diet L for a high daily LWG. Correspondingly, in recent studies (Huuskonen et al. 2007, Huuskonen et al. 2008, Huuskonen 2009a) with heavy dairy-breed bulls, rapeseed meal supplementation did not improve the growth rate, as also observed with heavy steers (Steen 1988b, Steen 1996a) and suckled beef bulls (Drennan et al. 1994) fed fish meal/soybean meal supplementation.

According to Lowman and Lewis (1991), the performance of bulls is not very sensitive to a range of protein concentrations between 130 and $180 \mathrm{~g}$ $\mathrm{CP} \mathrm{kg}{ }^{-1} \mathrm{DM}$. In the present study, the diet CP concentrations were 163, 177, 155 and $167 \mathrm{~g} \mathrm{CP} \mathrm{kg}^{-1}$ $\mathrm{DM}$ on diets EM, EH, LM and LH, respectively. However, the diet CP concentrations do not take into account the quality of protein. 
Vol. 20(2011): 151-168.

The carcass traits were unaffected by the concentrate protein concentration being consistent with recent studies (Huuskonen et al. 2007, Huuskonen et al. 2008, Huuskonen 2009a). On the contrary, increased protein intake tended to increase the carcass fatness of steers and heifers (Steen and Robson 1995, Steen 1996a). Although not observed in this study, protein supplementation of high (D value about $710 \mathrm{~g} \mathrm{~kg}^{-1} \mathrm{DM}$ ) digestibility silage tended to reduce carcass fatness but had no effect with medium (D value about $650 \mathrm{~g} \mathrm{~kg}^{-1} \mathrm{DM}$ ) digestibility silage (Steen 1988b). It seems that the opportunities to affect carcass fatness by protein supplement may be limited since the carcass fatness on grass silage-based feeding is also dependent on the quality of the silage.

\section{Eating quality}

The results of the present study showed that the average sensory quality of the loins was assessed good or acceptable by the sensory panel. In fact, the analysed beef samples were evaluated as tender, quite juicy and quite tasty.

Beef from the bulls on diet LH had the best sensory quality and lowest shear force values, whereas EH beef had the lowest sensory quality and the highest shear force values. In this study, the measured average Warner-Bratzler shear force value of $4.3 \mathrm{~kg} \mathrm{~cm}^{-2}$ for the beef was lower than the average value of $5.5 \mathrm{~kg} \mathrm{~cm}^{-2}$ achieved in a previous study in Finland (Honkavaara et al. 2003). The difference in these shear force values can be explained by prolongation of ageing time, which was 19 days (followed by freezing) in the former and ageing time of eight days (without freezing) in the latter. The former were Hf bulls, whereas most of the latter were milk breed bulls. In both cases, carcasses were suspended from the achilles tendon overnight. The method for shear force value measurement was also the same in both studies. Post mortem hanging of carcasses also affects meat shear force value. Keady et al. (2008) improved meat shear force value by aitch bone hanging instead of achilles tendon suspension. According to
Meisinger et al. (2006), liver-like off-flavours are specific to individual animals and $\mathrm{pH}$ and heme iron are not strongly related to off-flavour notes.

\section{Economy}

Price estimates have an important role in the economic comparison of feeding strategies. In this study, especially the price relation of $\mathrm{E}$ and $\mathrm{L}$ was an essential factor in the evaluation of different strategies.

Determination of the unit cost of silage requires information on both the first and the second cut of the sward. In this experiment, the re-growth was utilized as a pasture and the price setting had to be based on previous experiments. The quality of silage was not similar in the referred and in the present study but, as the quality effect was taken into consideration in the growth rates of the bulls, the subject of our interest was only the relative yield difference between $\mathrm{E}$ and L. For the determination of this difference, the earlier experiments were applicable.

Berthiaume et al. (1996) concluded that in a steer's diet it is technically possible to compensate for a lower forage digestibility by an addition of grain, but it is not necessarily economical. They based their statement on the average daily gain without including any price information in their analysis. Giving economic values to the inputs and outputs may change the result considerably as indicated in our study. Price relations are highly dependent on the economic environment where the beef producers operate and, therefore, the results of this study cannot be generalized. The study does, however, show that it is important to pay attention to the economic analysis, not only to growth rates, while seeking a profitable feeding strategy for finishing bulls.

All the tested feeding strategies gave nearly the same return for a beef producer. Moreover, the sensitivity analysis proved that this result is very stable; the price changes affect more the level of the return than the ranking of the treatments. Thus, the beef producer can adjust the harvesting time and make the feeding decisions according to farm- 


\section{Manninen, M. et al. Silage digestibility and concentrate protein in feeding of bulls}

specific resources and production conditions. The most important thing is to know the feeding value of the silage and, thus, be able to give a proper amount of protein supplementation to reach the intended growth rates.

\section{Conclusions}

Health was good and production performance high in the uninsulated housing conditions used. The results confirmed the importance of silage digestibility in the feeding of finishing beef bulls since early-cut silage improved the growth rate and shortened the finishing period significantly compared with later-cut silage. Animal performance was unaffected by the concentrate protein concentration and, thus, use of concentrate of higher protein concentration was not beneficial. All carcass traits were unaffected by the treatments. The eating quality of the tested loins was good and treatments had only a minor effect on the yield of valuable cuts. The same economic performance was achieved with different feeding strategies, which allows the producers to adjust the feeding flexibly to the prevailing production conditions.

Acknowledgements. The authors are indebted to Mrs. Ulla Eronen and her staff for technical assistance during the experiment. The personnel of the Slaughterhouse of Lihakunta in Kuopio and the staff of the Finnish Meat Research Institute in Hämeenlinna are thanked for their help in slaughter procedures and meat evaluation. Doctor Seija Jaakkola is warmly thanked for her comments on the manuscript. The commercial protein compound was supplied by Raisio Feed Ltd, which is gratefully acknowledged.

\section{References}

AOAC 1990. Official Methods of Analysis. $15^{\text {th }}$ edition. AOAC INTERNATIONAL, Arlington, USA Vol. 1.

Aronen, I. 1990. Barley protein and rapeseed meal as protein supplements for growing cattle. Acta Agriculturae Scandinavica 40: 297-307.

Aronen, I., Toivonen, V., Ketoja, E. \& Öfversten, J. 1992. Beef production as influenced by stage of maturity of grass for silage and level and type of supplementary concentrates. Agricultural Science in Finland 1: 441-460.

Beever, D.E., Offer, N. \& Gill, M. 2000. The feeding value of grass and grass products. In: Hopkins, A. (ed.). Grass, it's production and utilization. Blackwell Science, Oxford, UK, pp. 140-195.

Berge, P., Culioli, J., Renerre, M., Touraille, C., Micol, D. \& Geay, Y. 1993. Effect of feed protein on carcass composition and meat quality in steers. Meat Science 35: 79-92.

Berthiaume, R., Buchanan-Smith, J.G., Allen, O.B. \& Veira, D.M. 1996. Prediction of liveweight gain by growing cattle fed silages of contrasting digestibility, supplemented with or without barley. Canadian Journal of Animal Science 76: 113-119.

Commission of the European Communities 1991. Community scale for the classification of carcases of adult bovine animals. Regulation (EEC) No 1208/81, Regulation (EEC) No 2930/81, Regulation (EEC) No 1026/91.

Cummins, B., Keane, M.G., O'Kiely, P. \& Kenny, D.A. 2007. Effects of breed type, silage harvest date and pattern of offering concentrates on intake, performance and carcass traits of finishing steers. Irish Journal of Agricultural and Food Research 46: 149-168.

Dawson, L.E.R., Kirkland, R.M., Ferris, C.P., Steen, R.W.J., Kilpatrick, D.J. \& Gordon, F.J. 2002. The effect of stage of perennial ryegrass maturity at harvesting, fermentation characteristics and concentrate supplementation, on the quality and intake of grass silage by beef cattle. Grass and Forage Science 57: 255-267.

Drennan, M.J. \& Keane, M.G. 1987. Responses to supplementary concentrates for finishing steers fed silage. Irish Journal of Agricultural Research 26: 115-127.

Drennan, M.J., Moloney, A.P. \& Keane, M.G. 1994. Effects of protein and energy supplements on performance of young bulls offered grass silage. Irish Journal of Agricultural and Food Research 33: 1-10.

European Commission 1971. Commission Directive $71 / 250 / E E C$. Determination of ash which is insoluble in hydrochloric acid. Official Journal No L 155/13, 3031 (Method B).

Friedel, K. 1990. Die Schätzung des energetischen Futterwertes von Grobfutter mit Hilfe einer Cellulasemethode. [The estimation of the energetic feeding value of roughages by means of a cellulase method]. Wissenschaftliche Zeitschrift Universitet Rostock, N-Reihe 39: 78-86.

Haacker, K., Block, H.J. \& Weissbach, F. 1983. Zur kolorimetrischen Milchsäurebestimmung in Silagen mit pHydroxydiphenyl. [On the colorimetric determination of lactic acid in silages with p-hydroxydiphenyl]. Archiv für Tierernährung 33: 505-512.

Honkavaara, M., Rintasalo, E., Ylönen, J. \& Pudas, T. 2003. Meat quality and transport stress of cattle. Deutsche Tierärztliche Wochenschrift 110: 125-128.

Huhtanen, P.J., Blauwiekel, R. \& Saastamoinen, I. 1998. Effects of intraruminal infusions of propionate and butyrate with two different protein supplements on milk production and blood metabolites in dairy cows receiving grass silage based diet. Journal of the Science of Food and Agriculture 77: 213-222.

Huhtanen, P., Khalili, H., Nousiainen, J.I., Rinne, M., Jaakkola, S., Heikkilä, T. \& Nousiainen, J. 2002. Prediction of the relative intake potential of grass silage by dairy cows. Livestock Production Science 73: 111-130. 
Vol. 20(2011): 151-168.

Huhtanen, P., Rinne, M. \& Nousiainen, J. 2007. Evaluation of the factors affecting silage intake of dairy cows: a revision of the relative silage dry-matter intake index. Animal 1: 758-770.

Huida, L., Väätäinen, H. \& Lampila, M. 1986. Comparison of dry matter contents in grass silages as determined by oven drying and gas chromatographic water analysis. Annales Agriculturae Fenniae 25: 215-230.

Huuskonen, A. 2009a. The effect of cereal type (barley versus oats) and rapeseed meal supplementation on the performance of growing and finishing dairy bulls offered grass silage-based diets. Livestock Science 122: 53-62.

Huuskonen, A. 2009b. Concentrate feeding strategies for growing and finishing dairy bulls offered grass silagebased diets. Doctoral Dissertation. Faculty of Agriculture and Forestry of the University of Helsinki. MTT Agrifood Research Finland, Jokioinen, Finland. MTT Science 1: $99 \mathrm{p}$.

Huuskonen, A., Khalili, H. \& Joki-Tokola, E. 2007. Effects of three different concentrate proportions and rapeseed meal supplement to grass silage on animal performance of dairy-breed bulls with TMR feeding. Livestock Science 110: 154-165.

Huuskonen, A., Khalili, H. \& Joki-Tokola, E. 2008. Need for protein supplementation in the diet of growing dairy bulls fed total mixed ration based on moderate digestible grass silage and barley. Agricultural and Food Science 17: 109-120.

Keady, T.W.J., Lively, F.O., Kilpatrick, D.J. \& Moss, B.W. 2008. The effects of grain treatment, grain feed level and grass silage feed value on the performance of and meat quality from finishing beef cattle. Animal 2: 149-159.

Keady, T.W.J., Mayne, C.S. \& Fitzpatrick, D.A. 2000. Prediction of silage feeding value from the analysis of the herbage at ensiling and effects of nitrogen fertilizer, date of harvest and additive treatment on grass silage composition. The Journal of Agricultural Science 134: 353-368.

Kuoppala, K., Rinne, M., Nousiainen, J. \& Huhtanen, P. 2008. The effect of cutting time of grass silage in primary growth and regrowth and the interactions between silage quality and concentrate level on milk production of dairy cows. Livestock Science 116: 171-182.

Lowman, B.G. \& Lewis, M.L. 1991. The feeding and management of intensively reared bulls: conventional compared with organic. In: Haresign, W., Cole, D.J.A. (eds.). Recent Advances in Animal Nutrition. Butterworth-Heinemann Ltd, Oxford, pp. 181-209.

Manninen, M., Jauhiainen, L., Ruusunen, M., Soveri, T., Koho, N. \& Pösö, R. 2010. Effects of concentrate type and level on the performance and health of finishing Hereford bulls given a grass silage-based diet and reared in cold conditions. Livestock Science 127: 227-237.

Martinsson, K. 1990. The effect of forage digestibility and concentrate supplementation on performance of finishing bulls. Swedish Journal of Agricultural Research 20: 161-167.

McCullough, H. 1967. The determination of ammonia in whole blood by direct colorimetric method. Clinica Chimica Acta 17: 297-304.

McDonald, P., Henderson, A.R. \& Heron, S.J.E. 1991. The biochemistry of silage. $2^{\text {nd }}$ ed. Chalcombe Publications. Bucks, UK. 340 p.

Meisinger, J.L., James, J.M. \& Calkins, C.R. 2006. Fla- vor relationships among muscles from the beef chuck and round. Journal of Animal Science 84: 2826-2833.

Ministry of Agriculture and Forestry 1995. Hot carcass weight reduction and carcass classification. Decision of Ministry of Agriculture and Forestry, Finland 2.6.1995. Dnro 2691/00/95.

MTT 2006. Rehutaulukot ja ruokintasuositukset (Feed tables and feeding recommendations). [online]. Jokioinen: MTT Agrifood Research Finland. Published 14.2.2006, [cited 31.5.2009]. Available at: http://www.mtt.fi/rehutaulukot/. URN:NBN:fi-fe20041449

Nadeau, E., Hessle, A., Rustas, B.-O. \& Johnsson, S. 2002. Prediction of silage intake by Charolais bulls. In: Durand, J.-L., Emile, J.-C., Huyghe, C., Lemaire, G. (eds.). Multi-Function Grasslands, Quality Forages, Animal Products and Landscapes. Proceedings of the $19^{\text {th }}$ General Meeting of the European Grassland Federation, 27-30 May, La Rochelle, France. pp. 220-221.

Niemi, J. \& Ahlstedt, J. (eds.) 2008. Finnish Agriculture and Rural Industries 2008. MTT Economic Research, Helsinki, Finland. Publications 108a, 96 p.

ProAgria 2009a. Enterprise Budgets in Agriculture. ProAgria Association of Rural Advisory Centres, Vantaa, Finland. Publications 1081. 46 p. (In Finnish).

ProAgria 2009b. Production results 2008. ProAgria Association of Rural Advisory Centres, Vantaa, Finland. (In Finnish). http://www.proagria.fi/palvelut/maito/sailorehu Lohkotietopankki2008_tulosseminaari.pdf.

Rinne, M., Huhtanen, P. \& Jaakkola, S. 2002. Digestive processes of dairy cows fed silages harvested at four stages of grass maturity. Journal of Animal Science 80: 1986-1998.

Rinne, M., Jaakkola, S., Kaustell, K., Heikkilä, T. \& Huhtanen, P. 1999. Silages harvested at different stages of grass growth v. concentrate foods as energy and protein sources in milk production. Animal Science 69: 251-263.

Rinne, M. \& Nykänen, A. 2000. Timing of primary growth harvest affects the yield and nutritive value of timothy-red clover mixtures. Agricultural and Food Science in Finland 9, 2: 121-134.

SAS 2004. SAS/STAT $9.1 /$ User's Guide/. SAS Institute Inc., Cary, NC, USA, $5121 \mathrm{p}$.

Schroeder, G.F. \& Titgemeyer, E.C. 2008. Interaction between protein and energy supply on protein utilization in growing cattle: A review. Livestock Science 114: 1-10.

Scollan, N.D., Sargeant, A., McAllan, A.B. \& Dhanoa, M.S. 2001. Protein supplementation of grass silages of differing digestibility for growing steers. Journal of Agricultural Science, Cambridge 136: 89-98.

Somogyi, M. 1945. A new reagent for the determination of sugars. Journal of Biological Chemistry 160: 61-68.

Steen, R.W.J. 1988a. Factors affecting the utilization of grass silage for beef production. In: Frame, J. (ed.). Efficient Beef Production from Grass. Occasional Symposium No. 22, Hurley, British Grassland Society, pp. 129-139.

Steen, R.W.J. 1988b. The effect of supplementing silage-based diets with soya bean and fish meals for finishing beef cattle. Animal Production 46: 43-51.

Steen, R.W.J. 1992. The performance of beef cattle given silages made from perennial ryegrasses of different maturity groups, cut on different dates. Grass and Forage Science 47: 239-248. 


\section{AGRICULTURAL AND FOOD SCIENCE}

Manninen, M. et al. Silage digestibility and concentrate protein in feeding of bulls

Steen, R.W.J. 1996a. Effects of protein supplementation of grass silage on the performance and carcass quality of beef cattle. Journal of Agricultural Science, Cambridge 127: 403-412.

Steen, R.W.J. 1996b. Factors affecting the optimum protein content of concentrates for beef cattle. Research on beef production. Occasional Publication No. 22. Agricultural Research Institute of Northern Ireland, 53-59.

Steen, R.W.J. \& Kilpatrick, D.J. 2000. The effects of the ratio of grass silage to concentrates in the diet and restricted dry matter intake on the performance and carcass composition of beef cattle. Livestock Production Science 62: 181-192.

Steen, R.W.J., Kilpatrick, D.J. \& Porter, M.G. 2002. Effects of the proportions of high or medium digestibility grass silage and concentrates in the diet of beef cattle on liveweight gain, carcass composition and fatty acid composition of muscle. Grass and Forage Science 57: 279-291.

Steen, R.W.J. \& Moore, C.A. 1988. A comparison of silage-based and dried forage-based diets for finishing beef cattle. Animal Production 47: 29-37.

Steen, R.W.J. \& Moore, C.A. 1989. A comparison of silage-based and dried forage-based diets, and the effects of protein supplementation of a silage-based diet for finishing beef cattle. Animal Production 49: 233-240.

Steen, R.W.J. \& Robson, A.E. 1995. Effects of forage to concentrate ratio in the diet and protein intake on the performance and carcass composition of beef heifers. Journal of Agricultural Science, Cambridge 125: 125-135.

Swatland, H.J. 2000. Meat Cuts and Muscle Foods. An international glossary. Nottingham University Press, U.K. pp. 68-69.

Titgemeyer, E.C. \& Löest, C.A. 2001. Amino acid nutrition: Demand and supply in forage-fed ruminants. Journal of Animal Science 79 (E. Suppl.): E180-E189.

Vanhanen, L. 2009. Harvest time and fertilizing effect to quality and amount of silage. Thesis. Savonia University of Applied Sciences. 48 p. (In Finnish, Abstract). http:// urn.fi/URN:NBN:fi:amk-200905062472.

Van Soest, P.J., Robertson, J.B. \& Lewis, B.A. 1991. Methods for dietary fiber, neutral detergent fiber and nonstarch polysaccharides in relation to animal nutrition. Journal of Dairy Science 74: 3583-3597.

Waterhouse, A., Laird, R. \& Arnot, D.P. 1985. Responses to protein supplements in silage-fed finishing steers: effects of silage quality and supplement type. Animal Production 40: 538 (Abstract 68). 